\title{
PERSPEKTIF MAHASISWA DALAM PERMASALAHAN PENGGUNAAN BUKU TEKS BAHASA INGGRIS DI SEKOLAH DASAR
}

\section{(STUDENTS' PERSPECTIVE IN PROBLEMS USING ENGLISH TEXTBOOKS IN PRIMARY SCHOOLS)}

\author{
Syaifur Rochman
}

Universitas Jenderal Soedirman

Jalan Dr. Suparno, Kampus Unsoed Karangkangkal, Purwokerto, Jawa Tengah 53123 Indonesia

Pos-el: rochman_syaifur@hotmail,com

Diterima: 29 Oktober 2013; Direvisi: 2 Desember 2013; Disetujui: 3 Desember 2013

\begin{abstract}
Textbooks are prepared by selecting materials having original and permanent value. Various text books are prepared for different subjects for various levels of education, such as English for students of elementary school. Today, English text books have special importance. This article aims at seeing problems and finding out some solutions in the utilizing of English text books for students at elementary school in Purwokerto area, Central Java. The data are taken from the result of Focus Group Discussion (FGD) amongst students of Jenderal Soedirman University taking a subject called Classroom Action Research. It reveals that the text books are not in accordance with needs, earning money is the main aim in the use of text books.Thequality of text books is poor, and knowledge is presented in unconnected form. Besides, no proper attention is paid to methods of teaching.The textbooks are absence of necessary pictures, and suitable illustrations, and mistakes on printing and language.
\end{abstract}

Keywords: text books, English for students of elementary school, Purwokerto

\begin{abstract}
Abstrak
Buku teks disiapkan dengan cara memilih bahan-bahan yang memiliki nilai permanen dan orisinal. Berbagai macam buku teks disiapkan untuk subyek yang berbeda dengan latar belakang pendidikan yang beragam, seperti bahasa Inggris untuk sekolah dasar. Saat ini, buku teks bahasa Inggris sangat penting. Artikel ini bertujuan untuk melihat masalah-masalah dan mencari solusi dalam penggunaan buku teks untuk siswa sekolah dasar di wilayah Purwokerto, Jawa Tengah. Data diperoleh dari hasil Diskusi Kelompok Terpusat (FGD) di antara mahasiswa Universitas Jenderal Soedirman yang sedang mengambil mata kuliah Penelitian Tindakan Kelas. Hasil penelitian menunjukkan bahwa buku teks tidak sejalan dengan kebutuhan siswa. Menghasilkan uang adalah tujuan utama dalam penggunaan buku teks. Kualitas buku teks buruk dan isinya tidak berkaitan satu sama lain. Selain itu, tidak ada perhatian khusus yang diberikan untuk metode pengajaran; ketiadaan gambar-gambar dan ilustrasi yang diperlukan; dan banyak kesalahan bahasa dan penulisan.
\end{abstract}

Kata kunci: buku teks, bahasa Inggris untuk siswa SD, Purwokerto

\section{Pendahuluan}

Beberapa praktisi pengajaran bahasa Inggris di dunia percaya terhadap pentingnya penggunaan buku teks dalam proses pembelajaran di kelas. Tetapi, beberapa lainnya berpendapat sebaliknya. Guru yang kompeten dalam bahasa Inggris dianggap lebih penting daripada buku teks. 
Guru tidak dapat digantikan perannnya oleh buku teks di dalam kelas.

Buku teks menjadi salah satu alat bantubelajar yang akan memperlancar guru dalam mengajar bahasa Inggris mengingat terbatasnya pengetahuan yang dapat diberikan kepada siswa.

Berbagai persoalan muncul dalam penggunaan buku teks sebagai pegangan dalam menyampaikan mata pelajaran di sekolah. Beberapa pihak berpandangan kurang sejalan dengan penggunan buku teks di kelas. Mereka khawatir bahwa hal ini dapat membebani pengeluaran keuangan orang tua siswa mengingat biasanya pembelian buku teks dan distribusinya tidak dilakukan oleh pemerintah.

Di Indonesia, pemerintah telah membuat regulasi untuk standardisasi buku teks yang dipergunakan di sekolah-sekolah, termasuk buku teks bahasa Inggris. Para penulis buku teks perlu memperhatikan aturan dan komposisi buku teks. Dengan demikian, penulis buku dan juga penerbit akan mengetahui rambu-rambu yang harus diperhatikan agar buku teks sesuai dengan yang telah ditentukan oleh pemerintah.

Pada kenyataannya, tidak banyak buku teks pelajaran di sekolah ditulis oleh ahli dalam bidangnya. Nampaknya, mereka tidak begitu tertarik menulis buku teks untuk pelajaran di sekolah. Seharusnya, mereka bisa menerapkan berbagai hasil penelitian yang sudah dilakukan (Ghozali, 2011).

Tulisan ini menjabarkan hasil penelitian untuk mengetahui berbagai persoalan dalam penggunaan buku teks, khususnya untuk mata pelajaran bahasa Inggris yang diajarkan di sekolah dasar. Selain itu, beberapa alternatif pemecahan masalah diuraikan juga yang diperoleh melalui FGD yang dilakukan oleh responden. Dengan begitu, tulisan ini dapat memberikan gambaran tentang kondisi yang terjadi terhadap penggunaan buku teks.

\section{KerangkaTeori}

Di Indonesia, beberapa guru bergantung kepada buku teks dalam mengajar (Alisjahbana, 1990). Melalui buku teks, guru dapat berpedoman pada fakta dan informasi yang telah disusun secara sistematis. Dengan kata lain, baik guru maupun siswa dapat menjalani proses pembelajaran yang terstruktur dan terencana agar mereka bisa mengikuti pelajaran dengan jelas.

Buku teks pelajaran bahasa Inggris harus mengikuti perkembangan ilmu pengetahuan dan teknologi di dunia. Dengan kata lain, kebutuhan siswa dalam menggunakan buku teks perlumenyesuaikan dengan kondisi terkini yang sedang berkembang (Alwasilah, 2004). Contohnya adalah penggunaan internet dalam proses pembelajaran. Internet dapat membantu mengembangkan pengetahuan bahasa Inggris siswa di luar kelas. Oleh karena itu, pengetahuan tentang internet perlu diintegrasikan ke dalam pembelajaran bahasa Inggris.

Buku teks yang telah dipergunakan selama beberapa periode perlu dilakukan evaluasi secara berkala. Masukan dari guru, siswa, dan juga pihak lain seperti orang tua siswa dan para ahli pengajaran bidang ilmu tersebut, akan menyempurnakan isi dan kualitas buku teks yang dipakai siswa (Alwasilah, 2005).

Dengan demikian, para ahli tersebut dapat membuktikan teori yang dihasilkan dari penelitian ke dalam implementasinya di lapangan. Buku teks seringkali harganya dirasakan mahal sehingga orang tua siswa yang menjadi cukup berat untuk menanggungnya (Alisjahbana, 1990).

Marzano dkk. (2001) mengatakan bahwa kepala sekolah dan guru mempunyai hak untuk menentukan buku yang dibutuhkan di kelas. Keterlibatan guru kelas dalam menentukan buku teks yang dipergunakan siswa menjadi perlu. Mereka 
merupakan pihak yang terkait langsung dengan siswa di kelas. Guru di kelas lebih mengetahui keseharian siswanya. Untuk mengatasi berbagai kesulitan yang dihadapi di kelas, guru memerlukan buku teks agar nantinya siswa bisa terbantu untuk mengikuti proses pembelajaran. Dengan demikian, buku teks yang digunakan harus sesuai dengan situasi dan kondisi yang dihadapinya.

Biasanya, sekolah menentukan begitu saja penggunaan buku teks dalam proses pembelajaran. Buku teks wajib yang dipergunakan tersebut penggunaannya harus selalu dimonitor secara terus-menerus. Hal ini sejalan dengan apa yang disarankan Darling-Hammond (2010), menurutnya selambatnya-lambatnya setiap dua tahun sekali, buku teks dilihat kekurangan dan permasalahan dalam implementasinya yang dihadapi guru dan siswa,agar buku teks dapat disempurnakan.

Cruz dkk. (2009) mengatakan bahwapemerintah harus memperhatikan buku teks di sekolah-sekolah. Mereka menyarankan bahwa pemerintah perlu memberikan penghargaan yang cukup kepada penulis buku yang dipergunakan di sekolah karena hal ini akan berefek pada kemajuan pendidikan di negara tersebut. Mereka menambahkan bahwa agar buku teks bisa diterbitkan dengan lebih kompetitif dan bermutu, pemerintah harus mendorong penerbit buku teks swasta agar ikut berpartisipasi. Dengan demikian, banyak ahli tertarik menulis buku teks untuk sekolah-sekolah.

Harmer (1998) menyatakan bahwa buku teks sebagai alat bantu belajar perlu dipersiapkan dengan serius dan disesuaikan dengan standar yang baik dalam pencetakannya. Selain itu, Ghozali (2011) menambahkan bahwa buku teks hendaknya dilengkapi dengan tabel, gambar, diagram, atau ilustrasi yang diperlukan agar tampilan buku teks tersebut menarik. Terkadang, tampilan buku menggunakan kertas berkualitas rendah dan tidak terjilid rapi sehingga dapat menurunkan motivasi baik siswa maupun guru untuk menggunakannya.

Wajib belajar yang dicanangkan di berbagai negara mengharuskan praktisi pengajaran memperhatikan kualitas buku teks. Shamin dkk. (2007) mengingatkan bahwa program tersebut perlu dilengkapi dengan sarana pendukungnya, seperti buku teks. Mereka menyarankan untuk mengundang praktisi dan ahli pengajaran untuk berkolaborasi dalam penulisan buku teks. Adanya sinergi antara keduanya, akan menghasilkan buku teks yang bermutu.

Richards (2001) menekankan perlu diadakannya penelitian dalam pengajaran, khususnya buku teks. Bidang ini layak memperoleh perhatian karena banyak pihak yang terkait dalam aktivitas pembelajaran di kelas, memandang buku teks merupakan bagian dari proses belajar mengajar. Evaluasi, kurikulum, dan ragam silabus untuk pengajaran adalah bidang kajian yang terkait dengan buku teks.

Pendapat di atas, mendapat dukungan dari Harmer (2001) yang menyatakan bahwa penelitian dalam bidang pengajaran harus selalu dilakukan untuk mengembangkan kualitas pendidikan. Buku teks acapkali menjadi pegangan guru dalam menyusun rencana pembelajaran di kelas. Terkadang, penjelasan guru tidak sepenuhnya dapat dipahami siswa. Untuk itu, siswa mengulang kembali pelajaran yang telah diberikanguru di kelas. Melalui buku teks, siswa dapat belajar di luar kelas secara mandiri, baik individu maupun berkelompok.

Richards (2006) menambahkan bahwa dalam mempelajari bahasa Inggris sebagai bahasa asing, siswa memerlukan buku teks. Bahasa Inggris sebagai bahasa asing, frekuensi pemakaiannya dalam kehidupan sehari-hari akan jarang ditemui. Selain itu, ekspos terhadap bahasa Inggris sebagai bahasa target juga sedikit. Oleh karena itu, 
buku teks untuk siswa yang sedang belajar bahasa Inggris sebagai bahasa asing, akan menjadi penting perannya.

\section{MetodePenelitian}

Penelitian ini bersifat kualitatif denganteknik survey yang mengungkapkan permasalahan-permasalahan buku teks bahasa Inggris yang dipergunakan di sekolah dasar, khususnya di Purwokerto. Responden menyampaikan beberapa alternatif pemecahan masalah yang dihadapi.

Responden adalah mahasiswa Program Studi S-1 Bahasa dan Sastra Inggris Universitas Jenderal Soedirman yang mengambil mata kuliah Classroom Action Research (CAR).Mata kuliah ini adalah salah satu mata kuliah wajib dalam kurikulum. Terdapat 74 mahasiswa yang terbagi dalam 2 kelas paralel, yaitu berdasarkan Nomor Induk Mahasiswa (NIM) ganjil dan genap. Mereka adalah responden penelitian ini, yang berjumlah 69 mahasiswa dari angkatan 2010, dan 5 mahasiswa lainnya dari angkatan 2009.

Selain perkuliahan, responden wajib mengikuti praktikum di sejumlah sekolah dasar di sekitar kampus Universitas Jenderal Soedirman agar dosen pengampu bisa melakukan pemantauan terhadap mereka. Responden melakukan observasi kelasdan diskusi dengan guru. Pada akhir kegiatan praktikum, mereka wajib membuat laporan tertulis.

Praktikum dilakukan dengan bimbingan dosen pengampu mata kuliah dan juga guru bahasa Inggris di kelas. Responden wajib melakukan kunjungan ke sekolah minimal \pm 3 jam per minggu. Beberapa responden, dengan seizin guru bahasa Inggris di kelasnya masing-masing, terkadang bertandang ke rumah mereka. Hal ini dikarenakan keterbatasan waktu guru bahasa Inggris selama di sekolah untuk tanya jawab dan diskusi dengan mereka.
Sesudah itu, responden dengan dosen pengampu praktikum mata kuliah CAR mengadakan FGD. Merekamembahas persoalan yang dihadapi dalam pembelajaran bahasa Inggris, diantaranya adalah buku teks bahasa Inggris di SD. Diskusi tentang buku teks ini berlangsung selama 2 kali pertemuan dengan waktu \pm 2 jam setiap pertemuannya. Dari hasil pengamatan serta diskusi dengan guru bahasa Inggris di sekolah dasar, responden memaparkan pendapatnya tentang permasalahan ketika buku teks bahasa Inggris dipergunakan di kelas.

Data penelitian ini diperoleh melalui FGD yang dilakukan responden setelah mereka mengobservasi kelas bahasa Inggris di beberapa sekolah dasar, wawancara dengan guru bahasa Inggris, dan berdiskusi dengan guru bahasa Inggris di sekolah dasar tersebut. Sebelumnya dosen telah membahas di kelas tentang criteria buku teks yang baik berdasarkan pendapat para ahli di bidangnya (Harmer, 1998; Marzanodkk., 2001); dan Shamindkk., 2007). Semua kegiatan tersebut merupakan aktivitas dalam praktikum yang dilakukan selama 14 kali pertemuan dan merupakan bagian dari perkuliahan yang dilaksanakan di kampus.

\section{Pembahasan}

Semua responden sependapat bahwa buku teks bahasa Inggris diperoleh melalui promosi penerbit ke sekolah. Beberapa reponden menyatakan bahwa buku teks ditentukan bersama antara kepala sekolah dengan guru kelas.

Meskipun demikian, sebagian kecil responden menyatakan bahwa di sekolah tempat mereka melakukan praktikum ternyata kepala sekolah yang menentukan penggunaan buku teks bahasa Inggris. Sesudah itu, guru bahasa Inggris diberitahu buku teks yang harus dipergunakan. Nampaknya, kepala sekolah lebih mendengarkan penjelasan dari petugas 
pemasaran dari penerbit yang tentu saja cenderung lebih berpikir secara bisnis.

Dikatakan oleh responden bahwa kebebasan guru memilih buku teks untuk mengajar bahasa Inggris di kelas perlu mendapatkan persetujuan dari pihak sekolah. Padahal, guru kelas tentunya lebih paham dengan kebutuhan siswanya. Penggunaan buku teks di kelas bertujuan sebagai alat bantu proses pembelajaran bahasa Inggris di kelas. Peningkatan kualitas pendidikan salah satunya dilakukan melalui penggunaan buku teks yang bermutu. Meskipun demikian, responden melihat bahwa sebagian guru bahasa Inggris kurang memiliki kebebasan dalam memilih buku teks yang sesuai dengan kebutuhan siswanya.

Responden melihat adanya dominasi penerbit besar terhadap buku teks yang beredar di sekolah dasar. Sebagian besar buku teks bahasa Inggris yang ada sepertinya ditulis oleh pengarang-pengarang dari kelompok penerbit yang sama. Responden berpendapat bahwa banyak buku teks ditulis oleh pengarang yang jejak rekamnya kurang dikenal. Lebih jauh, mereka juga mengatakan bahwa pemilihan buku teks bahasa Inggris di sekolah dasar lebih menekankan pada penerbitnya daripada pengarangnya.

Penelitian dalam bidang pengajaran, termasuk pengembangan buku teks bahasa Inggris di sekolah dasar perlu dilakukan. Mereka melihat bahwa hasil-hasil penelitian yang telah dilakukan selayaknya bisa diimplementasikan di kelas agar nantinya tidak hanya menjadi menara gading saja. Seharusnya, penerbit buku teks lebih banyak mengundang para ahli dan peneliti untuk menuliskan buku teks. Penerbit seharusnya memberikan insentif yang cukup agar para ahli tertarik menulis buku teks yang dipergunakan di sekolah. Dengan begitu, buku teks yang diterbitkan akan mempunyai mutu yang lebih berkualitas karena ditulis oleh para ahli.
Temuan lain yang mengemuka adalah permasalahan konteks sosial yang dipergunakan di buku teks bahasa Inggris untuk sekolah dasar. Dalam belajar bahasa Inggris sebagai bahasa asing, siswa perlu menguasai kompetensi komunikasi dalam aspek tata bahasa, sosiolinguistik, wacana, dan strategi. Sebagian besar praktisi pengajaran bahasa asing setuju dengan pandangan itu. Dengan demikian, buku teks yang dipergunakan mestinya mengacu kepada gagasan tersebut.

Responden berpendapat bahwa buku teks di sekolah dasar kurang memperhatikan konteks sosial yang harus diajarkan kepada siswa. Sudah barang tentu, konteks sosial yang dimaksudkan adalah yang sesuai dengan norma dan tradisi masyarakat di negara penutur asli bahasa Inggris. Pada umumnya, buku-buku teks bahasa Inggris di sekolah dasar isinya menggunakan konteks sosial lokal yang terkadang tidak sesuai dengan kebiasaan sehari-hari masyarakat penutur asli bahasa Inggris.

Responden melihat kurangnya pengenalan terhadap konteks sosial akan mengakibatkan kesalahpahaman ketika nantinya siswa mempraktikannya dengan penutur asli bahasa Inggris. Contohnya adalah perkenalan dalam bahasa Inggris yang normanya tidak menanyakan umur atau status perkawinan. Di Indonesia, kedua pertanyaan tersebut tidak termasuk tabu untuk disampaikan dalam suatu perkenalan, sedangkan di negara penutur asli bahasa Inggris kedua pertanyaan tersebut merupakan aspek privasi setiap individu yang tidak layak ditanyakan dalam sebuah perkenalan.

Responden sependapat dengan pandangan yang menyatakan bahwa terdapat beberapa aspek tradisi yang berseberangan antara negara kita dengan masyarakat barat. Tetapi, responden lain berargumentasi bahwa norma-norma yang tidak sejalan atau bahkan bertentangan dengan tradisi lokal, 
jangan dihilangkan begitu saja. Buku teks perlu menampilkan konteks sosial yang benar dan tidak memperkenalan konteks sosial yang tidak sesuai dengan tradisi masyarakat penutur asli bahasa Inggris. Perbedaan-perbedaan yang kontras antara konteks sosial lokal dengan negara barat tidak perlu ditampilkan dalam buku teks bahasa Inggris untuk sekolah dasar mengingat siswa baru mempelajari bahasa Inggris.

Beberapa responden menyarankan, guru bahasa Inggris bisa menjelaskan dengan menggunakan bahasa yang sesuai dengan tingkat umur siswa, tentang adanya ketidaksesuaian antara aspek budaya lokal dan budaya barat. Guru dapat menginformasikan kepada siswa tradisi masyarakat penutur asli bahasa Inggris yang terkadang kurang sejalan dengan norma masyarakat Indonesia. Tetapi, beberapa responden yang lain mengingatkan bahwa siswa bisa mempunyai persepsi yang negatif terhadap masyarakat penutur asli bahasa Inggris apabila guru menjelaskan masalah ini. Oleh karena itu, guru harus hati-hati dalam penyampaiannya.

Meskipun demikian, semua responden setuju bahwa siswa harus diperkenalkan dengan norma dan tradisi penutur asli bahasa Inggris melalui penekanan pada aspek-aspek umum dan tidak mengekspos pada hal-hal yang kontradiktif. Pengenalan itu dilakukan oleh penulis buku teks yang digunakan siswa di sekolah. Dengan begitu, siswa akan mempelajari bahasa Inggris sesuai dengan kompetensi komunikatif.

Responden juga melihat evaluasi buku teks bahasa Inggris di sekolah dasar sebagai permasalahan yang muncul. Evaluasi buku teks yang dipergunakan di sekolah harus dilakukan secara terus menerus. Pada praktiknya, buku teks bahasa Inggris di sekolah dasar tidak pernah dilakukan evaluasi. Sepertinya, guru menggunakan buku teks bahasa Inggris yang berbeda tiap tahunnya. Oleh karena itu, sulit untuk dilakukan evaluasi terhadap buku teks yang telah dipergunakan.

Buku teks yang bermutu diperoleh melalui mekanisme kompetisi yang tinggi antarpenulisnya. Persoalan yang muncul apabila buku teks yang dipergunakan di sekolah tanpa melalui proses seleksi yang ketat. Pada praktiknya, buku teks bahasa Inggris yang beredar diterbitkan berdasarkan ketentuan tim dari dalam penerbit itu sendiri. Responden melihat jarang ada buku teks bahasa Inggris ditentukan berdasarkan serangkaian proses seleksi. Ada sebagian kecil buku teks bahasa Inggris menuliskan nama editor isi dan bahasa. Tetapi, banyak buku teks bahasa Inggris yang hanya menampilkan nama pengarangnya saja. Dengan kata lain, responden tidak tahu apabila buku teks bahasa Inggris tersebut telah lulus uji seleksi dari pemerintah.

Selain itu, responden menyoroti kesalahan cetak maupun tata bahasa dalam buku teks bahasa Inggris. Responden melihat bahwa kondisi ini berdampak negatif bagi siswa di sekolah dasar karena mereka bisa mengingat terus tata bahasa dan penulisan kata yang salah.

Semua responden sependapat bahwa buku teks bahasa Inggris di sekolah dasar dapat dikategorikan mahal. Mereka berargumentasi bahwa penerbit seharusnya memberi potongan harga untuk buku teks mengingat siswa biasanya membeli dalam jumlah banyak. Pada kenyataannya, siswa membeli buku teks melalui sekolah dengan harga yang sama dengan harga di toko-toko buku komersial. Buku teks untuk pelajaran di sekolah memang masih mahal bagi sebagian masyarakat Indonesia.

Buku teks memang sudah disediakan pemerintah melalui perpustakaanperpustakaan di sekolah. Siswa bahkan dipinjami buku teks selama berlangsungnya proses pembelajaran. Upaya lain dari pemerintah adalah dengan mengunggah 
buku-buku teks yang wajib bagi siswa agar dapat dipergunakansiswa melalui internet. Hanya saja, responden melihat bahwa hampir di semua sekolah masih menetapkan buku-buku tambahan untuk melengkapi buku teks yang wajib.

Responden menyarankan disediakan waktu yang cukup bagi pengarang buku teks bahasa Inggris sebelum mereka menulis buku. Pengarang buku teks perlu melihat hasil-hasil penelitian yang berguna dalam penulisan buku teks bahasa Inggris. Mereka diharapkan menerima masukan dan saran para ahli bidang yang sesuai. Buku teks yang hendak terbit mestinya ditelaah oleh ahli yang kompeten, sehingga buku teks yang diterbitkan dapat mempunyai isi yang berkualitas.

Pemerintah perlu mengontrol kebijakan penggunaan buku teks bahasa Inggris di sekolah. Banyak penerbit swasta yang bersaing mempromosikan buku-buku teks terbitan mereka. Tetapi, kualitas isi buku dan tampilan buku teks seringkali diabaikan. Selain itu, harga buku teks yang dipergunakan di sekolah terasa memberatkan orang tua siswa. Oleh karena itu, pemerintah perlu mengatur peredaran buku teks di sekolah yang diterbitan oleh pihak swasta. Responden menyebutkan penggunaan buku 'Super Kids' terbitan Pearson Longman ELT sebagai contoh harga buku teks yang mahal yang digunakan oleh siswa di beberapa sekolah.

Pemerintah seyogyanya berusaha mendorong munculnya penulis buku teks potensial yang baru. Dengan semakin banyaknya penulis, guru dan siswa memiliki banyak pilihan. Buku teks yang berkualitas dengan harga yang relatif terjangkau akan menjadi pilihan untuk dipergunakan. Persaingan yang ketat dalam penerbitan buku teks dapat menciptakan iklim positif karena penerbit akan menawarkan buku teks yang terbaik agar dapat dipilih pengguna di pasar. Responden menyebutkan contoh buku teks 'LKS SD Briliant Bahasa Inggris' terbitan CV Swadaya Murni, sebagai buku yang isinya baik dan harganya cukup terjangkau.

Responden berharap pemerintah memacu peneliti mengembangkan buku teks, khususnya bahasa Inggris untuk sekolah dasar, agar dapat dipergunakan siswa secara benar. Eksperimen hendaknya selalu dilakukan karena ilmu pengetahuan dan teknologi perkembangannya juga cepat. Responden berharap bahwa hasil penelitian buku teks bahasa Inggris tidak hanya terhenti pada laporan kepada penyandang dana saja, tetapi ada tindak lanjut untuk implementasinya.

\section{Penutup}

Penggunaan buku teks bahasa Inggris di sekolah dasar nampaknya tidak didasarkan atas kebutuhan siswa. Banyak penerbit buku teks bahasa Inggris yang lebih memfokuskan pada pemasaran bukunya agar laku terjual. Akibatnya, di lapangan banyak dijumpai buku teks yang kualitas isi maupun tampilannya terkesan seadanya.

Buku teks bahasa Inggris untuk sekolah dasar masih sedikit memperhatikan kesesuaian antara metode pengajaran dengan isi buku teks. Mestinya, buku teks memfokuskan pada penerapan pendekatan komunikatif dalam proses belajar mengajarkan. Oleh karena itu, aktivitasaktivitas dalam buku teks bahasa Inggris untuk siswa sekolah dasar harus memiliki prinsip dasar kesenjangan informasi agar siswa bisa mencari informasi dari pihak lain melalui komunikasi.

Pemerintah disarankan untuk mengharuskan evaluasi terhadap buku teks yang dipergunakan untuk mengajar di sekolah dasar. Sedikitnya, setiap setahun sekali buku teks yang dipakai di beberapa sekolah dasar perlu dilihat kelemahan dan kekurangannya. Pihak yang mengevaluasi seharusnya bersifat independen. Dengan 
8|Mabasan, Vol. 7 No. 2, Juli-Desember 2013:67-74

begitu, buku teks yang dipergunakan siswa sekolah dasar akan lebih dapat dipertanggungjawabkan mutunya.

\section{Daftar Pustaka}

Alisjahbana, Sutan Takdir. (1990). The Teaching of English in Indonesia. Dalam James Britton, Roberts E. Syeffer \& Ken Watson (Eds.). Teaching and Learning English Worldwide (pp. 315-327). Multilingual Matters: Philadelphia.

Alwasilah, A. Chaedar (2004, Mei 18). Revitalisasi Pendidikan Indonesia. Pikiran Rakyat. p. 21. (2005, Maret 12). Ada Apa Dengan Ilmu Bahasa? Pikiran Rakyat. p 38 .

Cruz, Barbara C. \& Thornton, Sthephen J. (2009). Teaching Social Studies to English Language Learners. New york: Routledge.

Darling-Hammond, Linda (2010). Evaluating Teacher Effectiveness. Washington: Centre for American Progress.

Ghozali, Imam (2011). "Pengembangan Buku Teks Integratif: Penelitian
Pengembangan Pendidikan di Sekolah Menengah Kejuruan Usaha Jasa Pariwisata di Yogyakarta". (Disertasi Doktor). Program Pascasarjana Universitas Sebelas Maret, Solo.

Harmer, Jeremy (1998). The Practice Of English Language Teaching. New York: Longman. . (2001). How to Teach English. Malaysia: Longman.

Marzano, Robert J., Pickering, Debra D., \& Pollock, Jane F. (2001). Classroom Instruction That Works. Virginia: Association for Curriculum and Supervision Development.

Richards, Jack K. (2001). Competence and Performance in Language Teaching. New York: Cambridge University Press.

Richards, Jack K. (2006). Communicative Language Teaching Today. New York: Cambridge University Press.

Shamin, Fauzia., Negash, Negusie., Chuku, Chinere., \& Demewoz, Netsanet (2007). Maximizing Learning in a Large Class: Issues and Option. Addis Ababa: British Council. 